\title{
Professors' Attitudes Toward Considering Spirituality and Spiritual Counseling and Training During Medical Education Among Medical Students: A Qualitative Study
}

\author{
Golnaz Mazaheri Nejad Fard ${ }^{1}$, Ali Asghar Asgharnejad Farid ${ }^{2}$, Neda Shahvaroughi Farahani ${ }^{1}$, \\ Zeinab Ghaempanah ${ }^{1} \&$ Mohammad Reza Pirmoradi $^{2}$ \\ ${ }^{1}$ Spiritual Health Research Center, Iran University of Medical Science, Tehran, Iran \\ ${ }^{2}$ School of Behavioral Sciences and Mental Health, Iran University of Medical Science, Tehran, Iran \\ Correspondence: Mohammad Reza Pirmoradi, School of Behavioral Sciences and Mental Health, Iran University \\ of Medical Science, Tehran, Iran. E-mail: Pirmoradi.mr@iums.ac.ir
}

Received: June 5, 2017

Accepted: June 23, 2018

Online Published: July 19, 2018

doi:10.5539/jmbr.v8n1p74

URL: https://doi.org/10.5539/jmbr.v8n1p74

\begin{abstract}
Background and aim: Spirituality is considered as one of the dimensions of health, along with physical, psychological and social health which includes an element of excellence and transcendence. However, it is unclear whether contemporary medical professors in Iran still considering this concept in their training program. This study assesses the professors' attitude toward considering spirituality and spiritual counseling and training during medical education among medical students.
\end{abstract}

Materials and methods: This is a qualitative study with conventional content analysis method. 43 participants, who were main stakeholders in medical education were selected by convenience sampling. Data were collected using structured interviews from September to October 2017, which continued until data saturation.

Ethical consideration: the principles of ethics and integrity in the research, citation and literature analysis were taken into consideration.

Finding: Three main themes and their categories were extracted from analysis of data. The themes are (1) helping to solve the students' spiritual problems and challenges (2), Psycho-spiritual characteristics of medical student (3), training spiritual concepts.

Conclusion: A majority of professors acknowledged the use of spirituality concepts in medical education. It seems that implementation of such programs requires attention to facilitating factors and challenges proposed by those involved.

Keyword: Professors' attitudes, Spiritual counseling, Spiritual training, Medical education.

\section{Introduction}

Spirituality is specifically a transcendent, highly subjective and multidimensional concept ascertained in the human lifestyle (Koenig, 2012; N Memaryan, Ghaempanah, \& Seddigh, 2017). It is manifested by faith, a relationship with a supernatural strength, believing in the existence of a power that helps people understand the meaning of life (Wong \& Yau, 2010), and finding purpose and meaning in work (Excellence, 2013). While spirituality can represent powerful sources of comfort, hope, coping, and meaning, they are often intricately entangled with psychopathology (Huguelet \& Koenig, 2009). Considering the importance of spiritual health in people's life, especially in students' lives, assessment of this existential dimension as a powerful source of the students has been regarded (JAFARI, DEHSHIRI, NAJAFI, \& SOHRABI, 2009); specially medical students who have always been vulnerable to stressful life conditions and intrapsychic challenges as a responsible for taking care of patients (Shaikh et al., 2004). Meanwhile, understanding the spiritual dimension of patients is very important for medical students (Nadereh Memaryan, Rassouli, Nahardani, \& Amiri, 2015; C. Puchalski, 2006), because holistic or comprehensive health care has become an obligatory issue for all medical team members (Babamohamadi, Ahmadpanah, \& Ghorbani, 2017). Additionally, religious beliefs and asking God for help affect positively on reducing patients' families' anxiety (Rabie Siahkali et al., 2014).

Although literature indicates the importance of studying spirituality in the population of medical students, nurses, and physicians (Curlin et al., 2007; Nadereh Memaryan et al., 2016; C. M. Puchalski, 2001; Sahebalzamani, 
Farahani, Abasi, \& Talebi, 2013), and the attitude of health care providers such as physicians and nurses toward spirituality has been studied in some research (Bahreynian, Delshad, Shakeri, \& Azizi, 2016; Koenig, Perno, \& Hamilton, 2017; Taylor, Mitchell, Kenan, \& Tacker, 2000), the viewpoint of medical professors who influence the education process of students significantly, about the importance of spirituality and necessity of spiritual counseling to medical students has not been studied, yet. Therefore, the present study is conducted with the aim of survey on professors' attitude toward considering spirituality and spiritual counseling and training during medical education regarding the students. The obtained results of this study can be used generally in improving the spiritual health and specifically in more effective counseling or therapy for medical students.

\section{Method}

A content analysis approach was used in this present qualitative study. Study population comprised 43 professors of Iran University of Medical Sciences through structured interviews. Participants were selected via convenience sampling from September to October 2017, which continued until data saturation. Data were collected using interviews based on the developed framework. A total of interviews were conducted with two professors of psychology. Interviews were recorded with permission of participants and turned into computer files and they were read, re-read and analyzed by the team of researchers.

\section{Results}

Of the 43 participants, 30(69\%) were men and 13(31\%) were women and all of them were Muslim. Three main themes emerged from analysis of data and categories created, including helping to solve the students' spiritual problems and challenges (Table 1), Psycho-spiritual characteristics of medical student (Table 2), and training spiritual concepts (Table 3); each is addressed as follows.

Table 1. Codes and categories associated with helping to solve the students' spiritual problems and challenges

\begin{tabular}{|c|c|c|c|}
\hline Theme & Category & Codes & $\begin{array}{c}\text { Abundance } \\
\text { (Percent) }\end{array}$ \\
\hline \multirow{20}{*}{$\begin{array}{l}\text { Helping to solve the } \\
\text { students' spiritual } \\
\text { problems and challenges }\end{array}$} & \multirow{9}{*}{$\begin{array}{l}\text { Use of consultative techniques } \\
\qquad(45.03 \%)\end{array}$} & Exploring causes of his/her problem & $16(14.41)$ \\
\hline & & Establishing a good/sincere relationship, & $12(10.81)$ \\
\hline & & talking to and empathy with him/her & \\
\hline & & Relaxing, reassuring and motivating him/her & $12(10.81)$ \\
\hline & & and mention his weaknesses and strengths and & \\
\hline & & abilities & \\
\hline & & Recommendations such as exercising, & $10(9)$ \\
\hline & & focusing on lessons, expanding social & \\
\hline & & relationships, and helping others & \\
\hline & \multirow{8}{*}{$\begin{array}{l}\text { Use of spiritual concepts } \\
\qquad(33.31 \%)\end{array}$} & Debating on purposes of creation, blessing of & $14(12.61)$ \\
\hline & & God, resurrection and spirituality & \\
\hline & & Advising to think about and study the & $11(9.9)$ \\
\hline & & meaning of being and life and Encouraging & \\
\hline & & participation in special courses of spirituality & \\
\hline & & Using Quranic Concepts and religious & $8(7.2)$ \\
\hline & & quotations & \\
\hline & & Advising to study the spiritual books & $4(3.6)$ \\
\hline & \multirow{3}{*}{$\begin{array}{l}\text { referral to others } \\
\qquad(21.6 \%)\end{array}$} & Counselor or psychologist & $10(9)$ \\
\hline & & Religious expert & $9(8.1)$ \\
\hline & & Psychiatrist & $5(4.5)$ \\
\hline
\end{tabular}

1) Helping to solve the students' spiritual problems and challenges: This was the first theme extracted from data which involves the steps of problem solving with respect to type of their challenges and contains three categories: use of spiritual concepts, use of consultative techniques and referral to others; among them, 45.03 percent of the responses were focused on consultative techniques and 33.31 percent of the results were about spiritual concepts. Also, 21.6 percent of the answers were about referring the students to others.

2) knowing the Psycho-Spiritual characteristics of medical students: Categories associated with this theme encompass professors' recognition of spiritual characteristics of medical students: Spiritual features, Positive ethical features, Religious features and Positive psychological features. Among them, more percentage of 
responses was related to psychological features $(41.01 \%)$, and the least was related to spiritual features $(14.08 \%)$.

3) Training spiritual concepts: According to medical professors' views, they help their students directly (53.48\%) and indirectly $(23.25 \%)$ on spiritual issues. In addition, $23.25 \%$ of them believed that their information on this context was not enough for teaching.

Table 2: Codes and categories related to psycho-spiritual characteristics of medical students theme.

\begin{tabular}{|c|c|c|c|}
\hline Theme & Category & Codes & $\begin{array}{c}\text { Abundance } \\
\text { (Percent) }\end{array}$ \\
\hline \multirow{12}{*}{$\begin{array}{c}\text { Psycho-Spiritual } \\
\text { characteristics of medical } \\
\text { students }\end{array}$} & \multirow{3}{*}{$\begin{array}{l}\text { Spiritual features } \\
\qquad(14.08 \%)\end{array}$} & Having purpose and meaning of life & $4(5.12)$ \\
\hline & & Forgiveness \& Patience & $3(3.84)$ \\
\hline & & Faith & $4(5.12)$ \\
\hline & \multirow{2}{*}{$\begin{array}{l}\text { Positive ethical features } \\
\qquad(19.23 \%)\end{array}$} & Humility, honesty and accountability & $10(12.82)$ \\
\hline & & Being a good model for others & $5(6.41)$ \\
\hline & \multirow{2}{*}{$\begin{array}{l}\text { Religious features } \\
\qquad(25.63 \%)\end{array}$} & $\begin{array}{l}\text { Believing in religious principles and doing } \\
\text { religious duties }\end{array}$ & $13(16.66)$ \\
\hline & & Trust in God & $7(8.97)$ \\
\hline & \multirow{5}{*}{$\begin{array}{l}\text { Positive Psychological Features } \\
\qquad(41.01 \%)\end{array}$} & Efforts and perseverance to achieve goals & $9(11.53)$ \\
\hline & & Constructive relationships with others & $7(8.97)$ \\
\hline & & Having self confidence & $6(7.69)$ \\
\hline & & Effective coping style against problems & $5(6.41)$ \\
\hline & & Adaptation & $5(6.41)$ \\
\hline
\end{tabular}

Table 3. Codes and categories associated with training spiritual concepts theme

\begin{tabular}{|c|c|c|c|}
\hline Theme & Category & Codes & $\begin{array}{c}\text { Abundance } \\
\text { (Percent) }\end{array}$ \\
\hline \multirow{9}{*}{$\begin{array}{l}\text { Training spiritual } \\
\text { concepts }\end{array}$} & \multirow{5}{*}{$\begin{array}{l}\text { Directly } \\
(53.48 \%)\end{array}$} & $\begin{array}{l}\text { Presenting the patterns of spiritually successful } \\
\text { persons }\end{array}$ & $7(16.27)$ \\
\hline & & Use of Quran and religious traditions & $6(13.95)$ \\
\hline & & Discussing & $5(11.62)$ \\
\hline & & Mentioning spiritual concepts while training & $3(6.97)$ \\
\hline & & $\begin{array}{l}\text { Expressing the beautiful effects of spiritual } \\
\text { concepts and the greatness of creation in the } \\
\text { students' view }\end{array}$ & $2(4.65)$ \\
\hline & Indirectly & Establishing a sincere relationship with student & $7(16.27)$ \\
\hline & $(23.25 \%)$ & $\begin{array}{l}\text { Encouraging students for participation in } \\
\text { spiritual classes and reading spiritual books }\end{array}$ & $3(6.97)$ \\
\hline & Not teaching spiritual concepts & Lack of enough knowledge to teach & $8(18.6)$ \\
\hline & $(23.25 \%)$ & Disbelief in the training of spiritual concepts & $2(4.65)$ \\
\hline
\end{tabular}

\section{Discussion}

The present study addressed attitude of professors toward considering spirituality and spiritual counseling and training during medical education among Iranian medical students via using the content analysis approach and also through interviewing 43 professors. The present qualitative research is efficient in exploring, identifying and explaining what happens in these sessions, since qualitative studies are the proper choice for exploring and understanding human relationships, such as education and care relationships (Nadereh Memaryan et al., 2017; Smith, 2015). 
Given the increasing number of studies on spirituality in health care settings (Huguelet \& Koenig, 2009; Koenig, 2012; N Memaryan et al., 2017), and the numerous scientific evidence on the efficacy of this issue in improving quality of care (C. M. Puchalski, 2001), spiritual health of practitioner especially medic is highly significant. Nevertheless, disregard this matter may result in a decreased quality of care and also well-being of medical members (White, 2006). By discovering three main themes, namely solving the spiritual problems and challenges, knowing the psycho-spiritual characteristics and training spiritual concepts among medical students we tried to make a better understanding of spiritual counselling and training necessity held for medical students. According to the majority of professors' point of view, the use of consultative techniques, after identification the spiritual problems of these students would be important and tremendously helpful. Talking about spiritual issues with students, not only solves their problems, but also establishes a good and sincere relationship, displays empathy, makes them calm and creates motivation in educational process. The necessity and efficiency of spiritual counseling in medical members in this study is similar to pastoral care principles (Proserpio, Piccinelli, \& Clerici, 2011; VandeCreek \& Burton, 2001) which includes providing spiritual services to physicians. Meanwhile, the use of spiritual concepts, such as the recommendation to think and study in the meaning of world and finding purpose and meaning of life, was less significant than the use of consultative techniques. In demonstrating such findings, it can be said that due to disagreements regarding to the definition of spirituality and its components in scientific sources, it seems that professors do not have coherent and comprehensive knowledge of spiritual concepts.

Through other stages, the professors consider Psycho-Spiritual characteristics of student that involve Spiritual features, Positive ethical features, Religious features and Positive psychological features. Almost half of the professors believed that positive psychological features were the most prominent attribute of a spiritual university student, but possessing positive psychological qualities for instance, efforts to achieve goals, perseverance, selfconfidence and effective coping styles are merely a part of a spiritual university students' personality. It seems that ambiguity in the definition of spirituality and lack of adequate and perfect understanding of the dimensions of spiritual personality plays an important role in explaining such findings. Hence, it seems that training of these concepts would be useful due to the fact that psycho-spiritual health of medical student and physicians is considered as one of the most helpful points in other studies (Yoon, Shin, Nian, \& Curlin, 2015). Also, these features would help students to get rid of meaninglessness and absurdity and sustain meaning and purpose in their work (Strobel, 2009; Yoon et al., 2015).

Training spiritual concepts is one of the most significant steps. Although professors discussing these concepts during medical education directly or indirectly, they admit inadequate information. Since the medical educators are recognizing spirituality as a core patient need, considering this issue is consequential. These findings are quite in line with surveys in other countries such as United Kingdom (UK) and United States (US) (Best, Butow, \& Olver, 2016; King, 2000; Lucchetti et al., 2012; M. Puchalski, Larson, \& Lu, 2001). Courses in medical schools and in psychiatric residency programs are being developed to address this essential issue (Grant, 2007; M. Puchalski et al., 2001). In this regard, surveys have identified that patients want their spiritual beliefs addressed in the clinical setting (D'Souza, 2007; C. M. Puchalski, 2001). Therefore, physician should be familiar with these concepts and using them in their treatment plan according to what they have already trained.

The themes provided in the present study contain delicate points that can be considered in these types of educating program in order to establish a better communication with student and comprehensive and effective teaching. The codes and themes also provide medic with a more effective teaching content that is consistent with the principles and strategies of comprehensive training (Pettus, 2002; C. Puchalski, 2006). We are beginning to see that medical professors need to be aware of the significance of spiritual concepts properly during the educational process. Moreover, due to the particular nature of educational relationship and the use of a professor who is a physician, these concepts are better understood. It should be noted that living in Iran with the Iranian-Islamic culture and the considerable figure of Islamic laws which emphasize more on religion, teaching spiritual concepts by academics can be helpful in avoiding misunderstand. The professors believed more in training spiritual concepts directly than indirect training, because it seems that direct methods of training spiritual concepts, specifically discussing, may be usual methods of teaching in Iran universities. However, it should be examined more.

There were some limitations of this study that should be considered. First, we used convenience sampling method that made us encounter with the problem of generalization of results. Next limitation of this research was small size of the sample group. Thus, it was suggested that further studies could be done with a larger population.

In conclusion, this study demonstrates that professors are aware of the importance of spirituality issues for medical students and they almost apply spiritual concepts. However, there would be the need of adequate knowledge of spirituality or training it, yet especially in clinical or medical settings. As a result, it is recommended to pay more attention to this issue more appropriately. 


\section{Acknowledgement}

We would like to express our gratitude to Spiritual Health Research Center, Iran University of Medical Science for supporting us in this project. Also, we would like to give our special thanks to all the professors who participated in this research; certainly, without their help this study could not have been accomplished.

\section{Conflict of interest}

All authors declare they have no conflict of interest.

\section{References}

Babamohamadi, H., Ahmadpanah, M.-S., \& Ghorbani, R. (2017). Attitudes Toward Spirituality and Spiritual Care among Iranian Nurses and Nursing Students: A Cross-Sectional Study. Journal of religion and health, 1-11.

Bahreynian, S. A.-M., Delshad, H., Shakeri, N., \& Azizi, F. (2016). Survey on Physicians Attitudes toward the Impact of the Spirituality Quantity on the Process of Patients' Treatment. Medical Ethics Journal, 6(20), 127153.

Best, M., Butow, P., \& Olver, I. (2016). Doctors discussing religion and spirituality: a systematic literature review. Palliative medicine, 30(4), 327-337.

Curlin, F. A., Lawrence, R. E., Odell, S., Chin, M. H., Lantos, J. D., Koenig, H. G., \& Meador, K. G. (2007). Religion, spirituality, and medicine: psychiatrists' and other physicians' differing observations, interpretations, and clinical approaches. American Journal of Psychiatry, 164(12), 1825-1831.

D'Souza, R. (2007). The importance of spirituality in medicine and its application to clinical practice. Medical Journal of Australia, 186(10), S57.

Excellence, B. P. (2013). The Joint Commission announces 2014 national patient safety goal. Joint Commission Perspectives.

Grant, A. (2007). Spirituality, health and the complementary medicine practitioner. Journal of the Australian Traditional-Medicine Society, 13(4), 207.

Huguelet, P., \& Koenig, H. G. (2009). Religion and spirituality in psychiatry: Cambridge University Press.

JAFARI, I., DEHSHIRI, G. R., NAJAFI, M., \& SOHRABI, F. (2009). RELATIONSHIP BETWEEN SPIRITUAL WELL-BEING AND MENTAL HEALTH OF THE UNIVERSITY STUDENTS.

King, D. E. (2000). Faith, spirituality, and medicine: toward the making of the healing practitioner: Psychology Press.

Koenig, H. G. (2012). Religion, spirituality, and health: the research and clinical implications. ISRN psychiatry, 2012.

Koenig, H. G., Perno, K., \& Hamilton, T. (2017). The spiritual history in outpatient practice: attitudes and practices of health professionals in the Adventist Health System. BMC Medical Education, 17(1), 102.

Lucchetti, G., Lucchetti, A. L. G., Espinha, D. C. M., de Oliveira, L. R., Leite, J. R., \& Koenig, H. G. (2012). Spirituality and health in the curricula of medical schools in Brazil. BMC Medical Education, 12(1), 78.

M. Puchalski, C., Larson, D. B., \& Lu, F. G. (2001). Spirituality in psychiatry residency training programs. International review of Psychiatry, 13(2), 131-138.

Memaryan, N., Ghaempanah, Z., Saeedi, M. M., Aryankhesal, A., Ansarinejad, N., \& Seddigh, R. (2017). Content of Spiritual Counselling for Cancer Patients Undergoing Chemotherapy in Iran: A Qualitative Content Analysis. Asian Pacific journal of cancer prevention: APJCP, 18(7), 1791.

Memaryan, N., Ghaempanah, Z., \& Seddigh, R. (2017). Spiritual interventions in Iran: A review article. SOJ Psychol 3 (1): 1-5. Spiritual interventions in Iran: A review article.

Memaryan, N., Jolfaei, A. G., Ghaempanah, Z., Shirvani, A., Vand, H., Ghahari, S., \& Bolhari, J. (2016). Spiritual care for cancer patients in Iran. Asian Pacific Journal of Cancer Prevention, 17(9), 4289-4294.

Memaryan, N., Rassouli, M., Nahardani, S. Z., \& Amiri, P. (2015). Integration of spirituality in medical education in iran: a qualitative exploration of requirements. Evidence-Based Complementary and Alternative Medicine, 2015.

Pettus, M. C. (2002). Implementing a medicine-spirituality curriculum in a community-based internal medicine residency program. Academic medicine: journal of the Association of American Medical Colleges, 77(7), 745-745. 
Proserpio, T., Piccinelli, C., \& Clerici, C. A. (2011). Pastoral care in hospitals: a literature review. Tumori, 97(5), 666-671.

Puchalski, C. (2006). Spirituality and medicine: curricula in medical education. Journal of Cancer Education, 21(1), 14-18.

Puchalski, C. M. (2001). The role of spirituality in health care. Proceedings (Baylor University. Medical Center), 14(4), 352.

Rabie Siahkali, S., Avazeh, A., Eskandari, F., Ghahremani, Z., Nematikhah, M., \& Aghvamy, M. (2014). Association between Religious Beliefs With Anxiety and Depression in Family Members of Hospitalized Patients. Journal of Zanjan University of Medical Sciences \& Health Services, 22(90).

Sahebalzamani, M., Farahani, H., Abasi, R., \& Talebi, M. (2013). The relationship between spiritual intelligence with psychological well-being and purpose in life of nurses. Iranian journal of nursing and midwifery research, $18(1), 38$.

Shaikh, B. T., Kahloon, A., Kazmi, M., Khalid, H., Nawaz, K., Khan, N., \& Khan, S. (2004). Students, stress and coping strategies: a case of Pakistani medical school. EDUCATION FOR HEALTH-ABINGDON-CARFAX PUBLISHING LIMITED-, 17, 346-353.

Smith, J. A. (2015). Qualitative psychology: A practical guide to research methods: Sage.

Strobel, H. W. (2009). Retaining and reclaiming the call of medicine Faculty Health in Academic Medicine (pp. 157-164): Springer.

Taylor, E., Mitchell, J. E., Kenan, S., \& Tacker, R. (2000). Attitudes of occupational therapists toward spirituality in practice. American Journal of Occupational Therapy, 54(4), 421-426.

VandeCreek, L., \& Burton, L. (2001). Professional chaplaincy: Its role and importance in healthcare. Journal of Pastoral Care \& Counseling, 55(1), 81-97.

White, G. (2006). Talking about spirituality in health care practice: A resource for the multi-professional health care team: Jessica Kingsley Publishers.

Wong, K. F., \& Yau, S. Y. (2010). Nurses' experiences in spirituality and spiritual care in Hong Kong. Applied Nursing Research, 23(4), 242-244.

Yoon, J. D., Shin, J. H., Nian, A. L., \& Curlin, F. A. (2015). Religion, sense of calling, and the practice of medicine: Findings from a national survey of primary care physicians and psychiatrists. Southern medical journal, $108(3), 189$.

\section{Copyrights}

Copyright for this article is retained by the author(s), with first publication rights granted to the journal.

This is an open-access article distributed under the terms and conditions of the Creative Commons Attribution license (http://creativecommons.org/licenses/by/4.0/). 